\title{
Risks and Trust in Internet Banking: Sample Evidence from Pathanamthitta District, Kerala.
}

\author{
G.S Aneeshkumar, Dr.Sybila Pius Fernandez, Dr.G.S Gireeshkumar \\ Research Scholar in Commerce, Bharathiar University, Coimbatore,(Assistant Professor, Post Graduate \\ Department of Commerce, BAM College, Thuruthicad, Pathanamthitta (Dist) Kerala), \\ Associate Professor \& Research Guide, Post Graduate \& Research Department of Commerce \\ St.Xavier's College for Women, Aluva, Ernakulum (Dist) Kerala, \\ Associate Professor \& Research Guide, Post Graduate \& Research Department of Commerce, Nirmala College, \\ Muvattupuzha, Ernakulam(Dist) Kerala.
}

\begin{abstract}
The marvelous kinds of innovation in technology and hard line blend of it with information technology made a paradigm shift in the banking industry. Technology itself created its world in the globe of human beings. The beginning of E- banking created a phenomenal system-Internet banking. Internet banking is a kind of systems that enable financial institution customers, individuals or businesses, to access accounts, transact business, or obtain information on financial products and services through the Internet. The main objectives of the paper are: 1.to understand the profile of Internet banking users in Pathanamthitta District. 2 .to identify the most widely used application of Internet banking. 3. to understand the influence of gender on various dimensions of risk in the usage of Internet banking. 4. to understand the influence of gender on various dimensions of trust in the usage of Internet banking. It is found that the popular internet banking services are; balance enquiry, followed by recharging mobile phones, banking service information and payment to other account. Most of the users are in the age group of 20-30 either employed or student with a monthly income of below 40,000 with educated with an average or advanced level of computer knowledge. The Chi-square test revealed that there is no statistically significant difference between the opinion of males and females towards risk are found. There is significant difference between males and females towards trust is found.
\end{abstract}

\section{Introduction}

Internet banking has made a sea change in the working of banks. Technological innovation has brought about the speedy processing and transmission of information, easy marketing of banking products, enhancement of customer access and awareness, wider networking and, regional and global links on an unprecedented scale. IT development has thus changed the product range, product development, service channels and type of banking services, as well as the packaging of such services. The IB in India way back in 1996. It is also called virtual banking or online banking. Internet banking includes the system that enables financial institution customers, individuals or businesses, access accounts, transact business, or obtain information on financial products and services on public or private network including Internet (Prakash and Malik 2008).

\section{Literature Review}

It is relevant to refer briefly to the previous studies and research in the related areas of the subject to find out and to fill up the research gaps, if any. Adoption, perception and usage of IB by customers are the areas examined in e-banking Literature. Weber (2003) has offered the perspective of risk perception: firstly perceived risk appears to be subjective and in its subjectivity ie.casual, people's behavior is mediated by the perceptions of risk. Secondly, risk perception like all other perception is relative. Perceived risk is defined as a consumers perceptions of the uncertainty and the possible undesirable consequences of buying a product or service (Littler or Melanthiou, 2006). LullMahamood (2007) strengthens the argument of security and privacy factor playing an important role in determining consumer adoption of IB.

Ming (2009) studied the risk factors in detail and identified that security risk, financial risk, performance risk, and time/ convenience risk have negatively affected the intention to adopt online banking in Taiwan. Kent Eriksson et.al; (2005) considered trust in IB as an antecedent to ease of use and perceived usefulness and found that trust has a positive effect on both ease of use and usefulness. Buttner and Goritz (2008) have associated with trust. The more risky a type of transaction is perceived to be, the more trust is required in order to engage in an interaction.

\section{Objectives of the Study}

- To understand the profile of Internet banking users in Pathanamthitta District.

- To identify the most widely used application of Internet banking. 
- To understand the influence of gender on various dimensions of risk in the usage of Internet banking.

- To understand the influence of gender on various dimensions of trust in the usage of Internet banking.

\section{Methodology}

The present study is based on the primary data collected through a structured questionnaire from the Internet banking users in Pathanamthitta district. Random sampling method was adopted for identifying 80 respondents (Table 1) from Thiruvalla, Mallappally and Ranni taluks of Pathanamthitta district. A five point Likert Scale with responses ranging from Disagree(1) to Agree (5) was used to measure the perceptions of respondents regarding the dimensions of risk and trust in the usage of Internet banking. The hypotheses are tested by using Chi-square test.

\section{Hypotheses}

H01: Customers' perceptions of risk dimensions in the usage of internet banking are independent of gender.

H02: Customers' perceptions trust dimensions in the usage of internet banking are independent of gender.

\section{Data Analysis and Hypotheses Testing}

Table 1 portrays the profile of internet banking users in Pathanamthitta district. Most of the users are in the age group of 20-30 either employed or student with a monthly income of below 40,000 with educated with an average or advanced level of computer knowledge. Prakash and Malik (2008) suggested that younger generations who are generally more computer -literate and have an affinity for the web are more likely to adopt Internet banking in India.

\begin{tabular}{|c|c|c|}
\hline \multicolumn{3}{|c|}{ Table 1 : Profile of Respondents } \\
\hline Respondents' Characteristics & $\begin{array}{l}\text { Number } \\
\text { Respondents } \\
\quad \mathrm{N}=\mathbf{8 0}\end{array}$ & Percentage \\
\hline \multicolumn{3}{|l|}{ Gender } \\
\hline Male & 40 & 50 \\
\hline Female & 40 & 50 \\
\hline \multicolumn{3}{|l|}{ Taluk } \\
\hline \multirow{3}{*}{$\begin{array}{r}\text { Thiruvalla } \\
\text { Mallappally } \\
\text { Ranni } \\
\end{array}$} & 27 & 33.75 \\
\hline & 27 & 33.75 \\
\hline & 26 & 32.5 \\
\hline \multicolumn{3}{|l|}{ Age } \\
\hline Below 20 & 5 & 6.25 \\
\hline \multirow{3}{*}{$\begin{array}{r}20-30 \\
30-40 \\
\text { Above } 40 \\
\end{array}$} & 55 & 68.75 \\
\hline & 11 & 13.75 \\
\hline & 9 & 11.25 \\
\hline \multicolumn{3}{|l|}{ Occupation } \\
\hline \multirow{4}{*}{$\begin{array}{r}\text { Student } \\
\text { Business man } \\
\text { Employee } \\
\text { Self-employed }\end{array}$} & 32 & 40 \\
\hline & 10 & 12.5 \\
\hline & 32 & 40 \\
\hline & 6 & 7.5 \\
\hline \multicolumn{3}{|l|}{ Monthly Income } \\
\hline \multirow{4}{*}{$\begin{array}{r}\text { Below } 20,000 \\
20,000-40,000 \\
40,000-60,000 \\
\text { Above } 60,000 \\
\end{array}$} & 42 & 52.5 \\
\hline & 30 & 37.5 \\
\hline & 6 & 7.5 \\
\hline & 2 & 2.5 \\
\hline \multirow{5}{*}{ Doctorate } & 5 & 6.25 \\
\hline & & \\
\hline & 33 & 41.25 \\
\hline & 40 & 50 \\
\hline & 2 & 2.5 \\
\hline \multirow{3}{*}{$\begin{array}{l}\text { Level of Knowledge to operate a } \\
\text { computer } \\
\text { Basic } \\
\text { Average } \\
\text { Advanced }\end{array}$} & 11 & 13.75 \\
\hline & 49 & 61.25 \\
\hline & 20 & 25 \\
\hline
\end{tabular}


Source: Primary Data

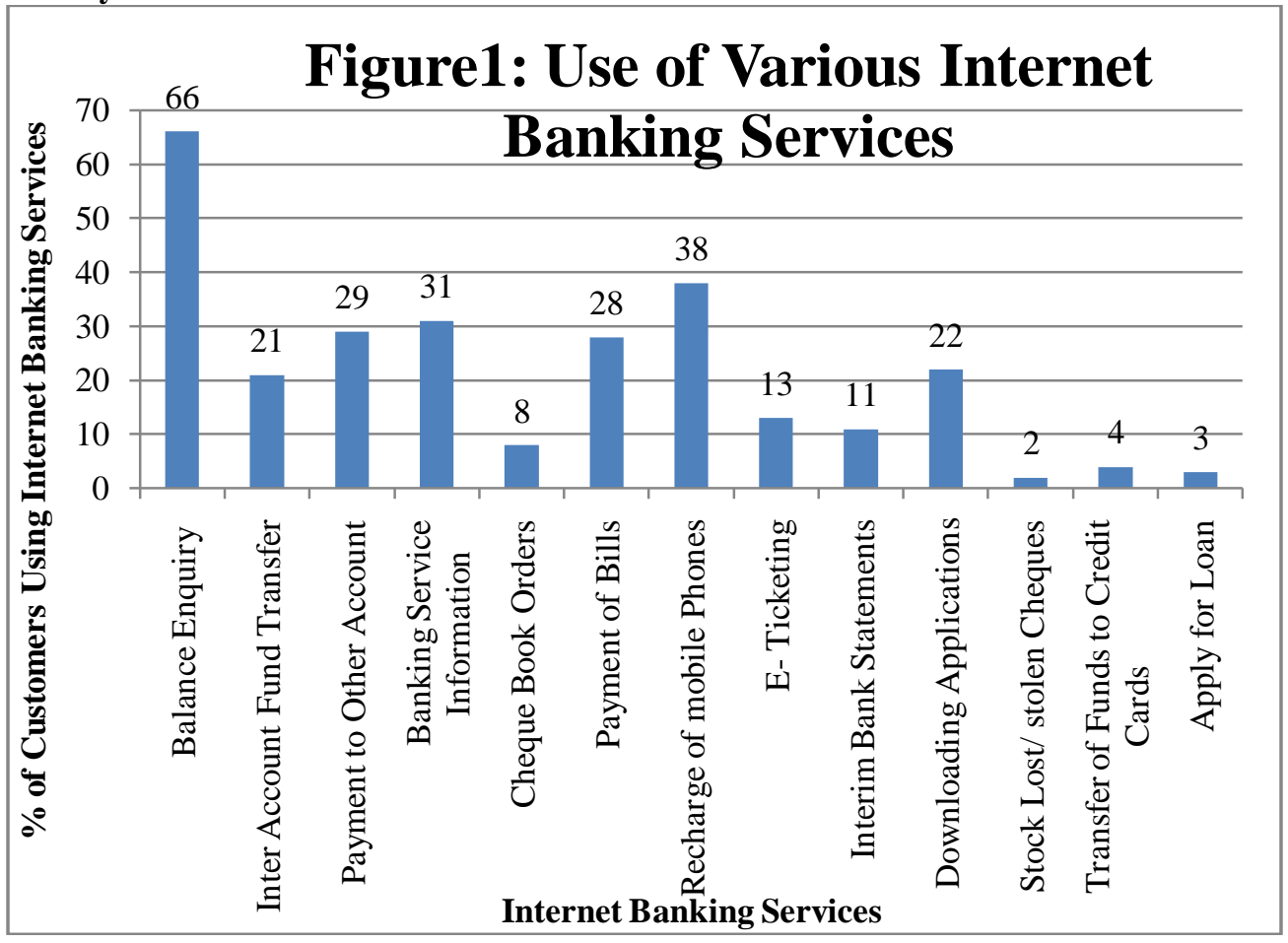

Figure 1 shows that the popular Internet banking services among the customers is balance enquiry, followed by recharging mobile phones, banking service information and payment to other account.

Hypotheses Testing

H01: Customers' perceptions of risk dimensions in the usage of internet banking are independent of gender.

Table 2: Chi-square Test; Customers' risk perception and Gender

\begin{tabular}{|c|l|l|l|l|l|}
\hline Sl.No & Association & $\begin{array}{l}\text { Table Value } \\
\text { @5\% level of } \\
\text { significance }\end{array}$ & $\begin{array}{l}\text { Calculated Value } \\
\text { of Chi-square }\end{array}$ & d.f & Results \\
\hline 1. & $\begin{array}{l}\text { Risk Perception and } \\
\text { Gender }\end{array}$ & 9.488 & 4.68 & 4 & There is no association \\
\hline
\end{tabular}

In the case of perception of risk, no statistically significant difference between the opinion of males and females is found i.e. since the calculated value is less than the table value, the researcher accept the null hypothesis. H02: Customers' perceptions trust dimensions in the usage of internet banking are independent of gender.

Table 3: Chi-square Test; Customers' Trust perception and Gender

\begin{tabular}{|c|l|l|l|l|l|}
\hline SI.No & Association & $\begin{array}{l}\text { Table Value } \\
\text { @5\% Level Of } \\
\text { Significance }\end{array}$ & $\begin{array}{l}\text { Calculated } \\
\text { Value Of Chi- } \\
\text { Square }\end{array}$ & D.F & Results \\
\hline $\mathbf{1 .}$ & $\begin{array}{l}\text { Trust Perception And } \\
\text { Gender }\end{array}$ & 9.488 & 38.6 & 4 & There Is Association \\
\hline
\end{tabular}

In the case of perception of trust, there is significant difference between males and females is found.i.e. Since the calculated value is more than the table value, the researcher rejects the null hypothesis.

\section{Conclusion}

Based on the survey results and analysis, it is found that the popular internet banking services are: balance enquiry, followed by recharging mobile phones, banking service information and payment to other account. Most of the users are in the age group of 20-30 either employed or student with a monthly income of below 40,000 with educated with an average or advanced level of computer knowledge. There is no statistically significant difference between the opinion of males and females towards risk are found. There is significant difference between males and females towards trust is found. The managerial implication of this study are for bank managers to take appropriate measures to educate users of internet banking to allay their apprehensions about the risk and trust associated with the use of Internet banking. 


\section{References}

[1]. Buttner, O. B \& Gorlitz.S, (2008), "Perceived Trust worthiness of online shops". Journal of Consumer Behavior, 7(1), 35-50.

[2]. Department of Technology's Banks (2011) Information age website. Online available: http//:ict.news.ir

[3]. E.U.Weber (2003), "Perception matters: Psychophysics for economists", Psychology and Economics. Oxford, U.K: Oxford University Press.

[4]. International Conference on Economics and Finance Research IPEDR vol.4 (2011) @ (2011) IACSIT Press, Singapore.

[5]. Kent Eriksson, Katri Kerem and Daniel Nilsson (2005), "Customer Acceptance of Internet banking in Estonia”, International Journal of Bank Marketing, Vol.23 No.2, pp.200-216

[6]. Li F (2011) E-Business; reinventing business in Information age. Translate by: Yaghoubi N, Khaksar SMS and Qarehchahi A (2011) Publication by: Univ. Sistan \& Baluchestan. Zahedan. pp: 7-11.

[7]. Littler D and Melanthiou, (2006), "Consumer perceptions of risk and uncertainty and the implications for behavior towards innovative retail services”. Manchester Business School, J .Retailing \& Consumer Services, 13,431-43.

[8]. Ming -Chi Lee (2009), "Factors influencing the Adoption of Internet Banking: An Integration of TAM and TPB with Perceived Risk and Perceived Benefit", Electronic Commerce Research and Applications, Vol. 8, pp. 130-141.

[9]. Prakash A and Malik G (2008), "Empirical study of Internet banking in India "CURIE, Vol.1, No.3, pp.83-92.

[10]. Sohail, M. S. and Shaikh, N. M. (2008), Internet banking and quality of service Perspectives from a developing nation in the Middle Easth, Online Information Review, Vol. 32 No. 1, 2008, pp. 58-72. 